\title{
Synthesis of $\operatorname{IgM}, \operatorname{IgG}$, and $\operatorname{Ig} \mathrm{A}$ in rheumatoid arthritis
}

\author{
K. POIKONEN, M. OKA, ${ }^{*}$ T. MÖTTÖNEN, ${ }^{*}$ I. JOKINEN, AND \\ H. ARVILOMMI
}

From the Public Health Laboratory and *Middle Finland Central Hospital, SF-40620 Jyväskylä 62, Finland

SUMMARY We studied the production of immunoglobulins by lymphocytes separated from the blood of 15 rheumatoid arthritis (RA) patients, of 12 patients suffering from other connective tissue diseases (CTD), and of 18 healthy controls. The production of $\operatorname{IgM}, \operatorname{IgG}$, and $\operatorname{IgA}$ in pokeweed-mitogen-stimulated cultures was measured by counting the number of plaque-forming cells (PFC) and by determining the concentration of secreted immunoglobulins by means of an enzyme immunoassay. Synthesis of immunoglobulins, particularly IgM and IgG, was lower than in other CTD patients or controls. The IgM response of RA patients was $20 \%$ and $29 \%$ (PFC and Ig concentration) that of the controls. The respective figures for $\operatorname{IgG}$ were $33 \%$ and $53 \%$ and for $\operatorname{IgA}$ $61 \%$ and $72 \%$.

The formation of antibodies against immunoglobulins is typical of rheumatoid arthritis (RA). These antibodies are known as the rheumatoid factors. With respect to responses in vivo against various antigens and observed levels of serum immunoglobulins there is controversy about antibody formation in RA. However, the majority of studies have demonstrated elevated levels of IgG, IgM, and IgA. ${ }^{1}$

Although in-vitro methods for studying antibody response at the cellular level have been used in laboratory animals for several years, only recently has it been possible to apply the same methodology to human cells. A major advance in this respect has been the development of plaque assays, in which the number of cells secreting various classes of immunoglobulins after stimulation with a mitogen is determined. ${ }^{23}$ Using this plaque technique and an enzyme-linked immunosorbent assay (ELISA) we studied the synthesis of IgG, IgM, and IgA in patients suffering from RA.

\section{Materials and methods}

Subjects. Fifteen patients with active, definite rheumatoid arthritis according to the ARA criteria were selected for study (Table 1). Ten of the patients were seropositive and five seronegative. None had received systemic corticosteroid therapy before test-

Accepted for publication 1 December 1981.

Correspondence to Dr H. Arvilommi, Public Health Laboratory, SF-40620 Jyväskylä 62, Finland. ing. Administration of nonsteroidal antiinflammatory agents was not stopped because of the study. A control patient group consisted of 12 patients with reactive arthritis, scleroderma, polymyositis, or fibrositis (Table 1). Normal controls were 18 healthy subjects from the laboratory staff.

Cell isolation. Mononuclear cells were separated from $30 \mathrm{ml}$ heparinised venous blood by centrifugation on Ficoll-Isopaque gradient. Cells from patients and paired normal donors were separated in parallel. Separated cells were washed 3 times in Hanks's balanced salt solution (HBSS) and resuspended in culture medium. The cell concentration was adjusted to $1 \times 10^{6}$ cells $/ \mathrm{ml}$.

Cell cultures. Cultures were prepared in $15 \times 100$ $\mathrm{mm}$ round-bottomed plastic tubes (Sterilin, Teddington Middlesex, England) in a final volume of $2 \mathrm{ml}$. The culture medium was RPMI-1640 (Flow Laboratories Ltd., Irwine, Scotland) supplemented with heat inactivated fetal calf serum (FCS, Flow Laboratories Ltd.), gentamicin $(15 \mu \mathrm{g} / \mathrm{ml}$, Schering Corporation, Kenilworth, USA), and L-glutamine ( 3

Table 1 Details of the patients and controls

\begin{tabular}{lrrll}
\hline Diagnosis & $n$ & Female & Male & Mean age in years $\pm S D$ \\
\hline RA & 15 & 7 & 8 & $43 \pm 18$ \\
Reactive arthritis & 5 & 2 & 3 & $37 \pm 13$ \\
Scleroderma & 3 & 3 & - & $49 \pm 11$ \\
Polymyositis & 1 & 1 & - & 50 \\
Fibrositis & 3 & 3 & - & $41 \pm 17$ \\
Controls & 18 & 12 & 6 & $31 \pm 8$ \\
\hline
\end{tabular}


$\mathrm{mg} / \mathrm{ml}$ ). Cells were cultured with (stimulated cultures) or without (unstimulated cultures) pokeweed mitogen (PWM, Gibco, New York, USA) at a final dilution of 1:100. Cultures were incubated for 5 days in a humid atmosphere of $5 \% \mathrm{CO}_{2}$ and $95 \%$ air at $37^{\circ} \mathrm{C}$. At the end of this period the cells were washed twice with $2 \mathrm{ml}$ HBSS and resuspended in $1 \mathrm{ml}$ of culture medium without FCS. The culture supernatants were stored at $-20^{\circ} \mathrm{C}$ for Ig determination.

Coupling protein-A to SRBC. Protein-A of Staphylococcus aureus (Pharmacia Fine Chemicals, Uppsala, Sweden) was coupled to SRBC with chromic chloride. ${ }^{2}$ One volume of protein-A $(0.5 \mathrm{mg} / \mathrm{ml})$ was mixed with 10 volumes of chromic chloride solution $\left(2.5 \times 10^{-4} \mathrm{M}\right)$ and one volume of packed, washed SRBC and incubated at $30^{\circ} \mathrm{C}$ for $1 \mathrm{~h}$. All reagents were prepared in $0.9 \% \mathrm{NaCl}$. After incubation the cells were washed 3 times in $0.9 \% \mathrm{NaCl}$ and resuspended in HBSS.

Plaque assay. The number of Ig-secreting cells was determined before culture (spontaneous plaqueforming cells) and at the end of culture period by a haemolytic plaque assay. ${ }^{3}$ Noble agar $(0.5 \%$ in HBSS containing $0.05 \%$ DEAE-dextran, Pharmacia Fine Chemicals) was heated to boiling and allowed to equilibrate at $46^{\circ} \mathrm{C}$ in a water bath. To $700 \mu$ l of agar was added $25 \mu$ l protein-A coupled SRBC (30\% suspension), $25 \mu \mathrm{l}$ rabbit antihuman immunoglobulin $(\mu-, \delta-$, or $\alpha$-specific, diluted 1:30 in saline, Dakoimmunoglobulins, Copenhagen, Denmark), $25 \mu \mathrm{l}$ guinea-pig complement (diluted 1:3 in saline), and $100 \mu \mathrm{l}$ cell suspension. This was then mixed and 3 separate $0.2 \mathrm{ml}$ drops of the mixture were pipetted into a plastic Petri dish. A $22 \times 32 \mathrm{~mm}$ glass coverslip was immediately placed over each drop, producing a thin layer of gel.

Plates were then incubated at $37^{\circ} \mathrm{C}$ for 4 to 6 hours. Plaques were counted using a stereo microscope. The number of antibody secreting cells was expressed as plaque forming cells (PFC) $/ 10^{6}$ viable cells as determined by trypan blue exclusion at the time of harvesting.

Ig-determination by enzyme-linked immunosorbent assay (ELISA). A double sandwich ELISA method was used for IgM, IgG, and IgA in the culture supernatants. ${ }^{4}$ Microtitre plates (Dynatech Laboratories Ltd., Sussex, England) were coated with antihuman IgM, IgG, or IgA antisera (Orion Diagnostica, Helsinki, Finland). The antisera were diluted 1:5000-1:10000 in 0.05 M carbonate buffer, pH 9.2, and $150 \mu \mathrm{l}$ was added to each well. The plates were incubated at $4^{\circ} \mathrm{C}$ overnight and then washed 3

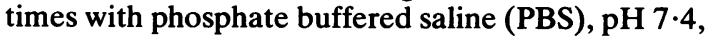
containing $0 \cdot 25 \%$ Tween 20 . The supernatants from lymphocyte cultures were diluted 1:10-1:80 in culture medium, and $150 \mu \mathrm{l}$ was added to each well. The plates were then incubated at $37^{\circ} \mathrm{C}$ for 1 hour, washed 3 times, and $150 \mu$ l of the alkaline phosphatase conjugated antihuman immunoglobulin serum (Orion Diagnostica), diluted 1:200 in PBS, was then added to each well.

After $1 \mathrm{~h}$ incubation at $37^{\circ} \mathrm{C}$ the plates were washed 3 times and $150 \mu \mathrm{l}$ p-nitrophenylphosphate $(1 \mathrm{mg} / \mathrm{ml}$, Sigma Chemical Company, Saint Louis, USA) in $1 \mathrm{M}$ diethanolamine-HCl buffer, $\mathrm{pH} 9 \cdot 8$, containing $0.5 \times 10^{-3} \mathrm{M} \mathrm{MgCl}_{2}$, was added to each well. The plates were then incubated at $37^{\circ} \mathrm{C}$. After $1 \mathrm{~h}$ the enzymatic reaction was stopped by adding $50 \mu \mathrm{l} 3 \mathrm{M} \mathrm{NaOH}$, and absorbance at $405 \mathrm{~nm}$ was measured with a Titertek Multiscan plate reader (Flow Laboratories Ltd.).

The immunoglobulin content of the samples was calculated from standard curves obtained with standard sera (Behringwerke, Marburg, Germany).

\section{Results}

IgM, IgG, and IgA producing cells after PWM stimulation. Lymphocytes cultured in the presence of PWM for 5 days were harvested, and plaque assays were performed to determine the number of Igproducing cells. The diagram in Fig. 1 shows the number of Ig-producing cells in $15 \mathrm{RA}$ patients and 11 normal controls. The number of the controls used

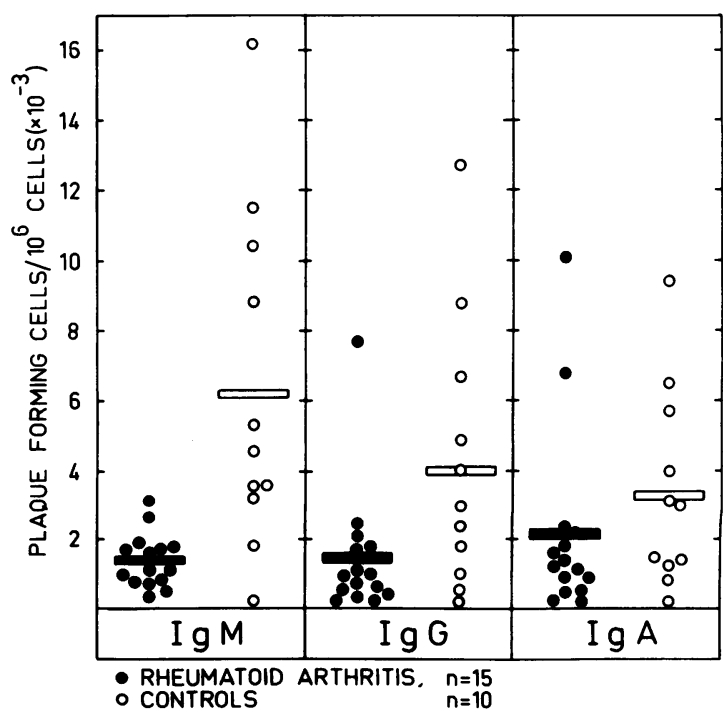

Fig. 1 Immunoglobulin secreting cells in PWM-stimulated lymphocyte cultures. Results are expressed as plaque-forming cells $(P F C) / 10^{6}$ viable cells determined by trypan blue exlusion (at the moment of plating). Bars represent arithmetic mean. The values of $R A$ patients are significantly different from the controls for $\operatorname{IgM}(p<0.001)$ and IgG $(p<0.05)$ by Student's t test. 
Table 2 Plaque-forming cells and Ig-concentrations in pokeweed-stimulated lymphocyte cultures

\begin{tabular}{|c|c|c|c|c|c|c|c|}
\hline \multirow[t]{2}{*}{ Group } & \multirow[t]{2}{*}{$n$} & \multicolumn{3}{|l|}{$P F C / 10^{6}$ cells } & \multicolumn{3}{|c|}{ Ig concentration, $n g / m l$} \\
\hline & & $\lg M$ & $\operatorname{Ig} G$ & $\operatorname{IgA}$ & $\operatorname{Ig} M$ & $I g G$ & $\operatorname{Ig} A$ \\
\hline $\begin{array}{l}\text { RA patients } \\
\text { Other patients } \\
\text { Controls }\end{array}$ & $\begin{array}{l}15 \\
12 \\
18\end{array}$ & $\begin{array}{l}1381 \pm 786+^{*} \\
5359 \pm 4796 \\
7039 \pm 5440\end{array}$ & $\begin{array}{l}1461 \pm 1867 \dagger^{* * *} \\
5359 \pm 6612 \\
4374 \pm 3362\end{array}$ & $\begin{array}{l}2167 \pm 2819 \\
4444 \pm 4849 \\
3573 \pm 2665\end{array}$ & $\begin{array}{c}330 \pm 180 \dagger^{*} * \\
1080 \pm 1020 \\
1140 \pm 1125\end{array}$ & $\begin{array}{c}600 \pm 380^{* *} \\
1425 \pm 1525 \\
1135 \pm 1355\end{array}$ & $\begin{array}{l}230 \pm 220 \\
560 \pm 855 \\
320 \pm 380\end{array}$ \\
\hline
\end{tabular}

Results expressed as arithmetic mean \pm SD.

tSignificantly different from controls, $p<0 \cdot 001$.

++ Significantly different from controls, $p<0.01$.

*Significantly different from other patients, $p<0.01$.

* Significantly different from other patients, $p<0.05$.

was only 11 because in some experiments the same control served for more than one patient sample. The number of IgM-producing cells among rheumatoid lymphocytes was highly significantly less $(p<0.001)$ than for controls. The difference between rheumatoid and normal lymphocytes for numbers of IgG-producing cells and total plaque-forming cells was also significant $(p<0 \cdot 05)$. Numbers of $\operatorname{IgA}$ forming cells were not statistically different.

For comparison we also collected samples from patients with other connective tissue diseases (Table 1). Table 2 shows the number of plaque-forming cells after PWM-stimulated culture of lymphocytes from RA patients, other CTD patients, and all the healthy controls. Fewer cells synthesising IgM or IgG were detected in rheumatoid blood than in blood from patients with other CTD or the controls. The IgM response of RA patients was $20 \%$ and $29 \%$ (PFC and Ig concentration) that of the controls. The

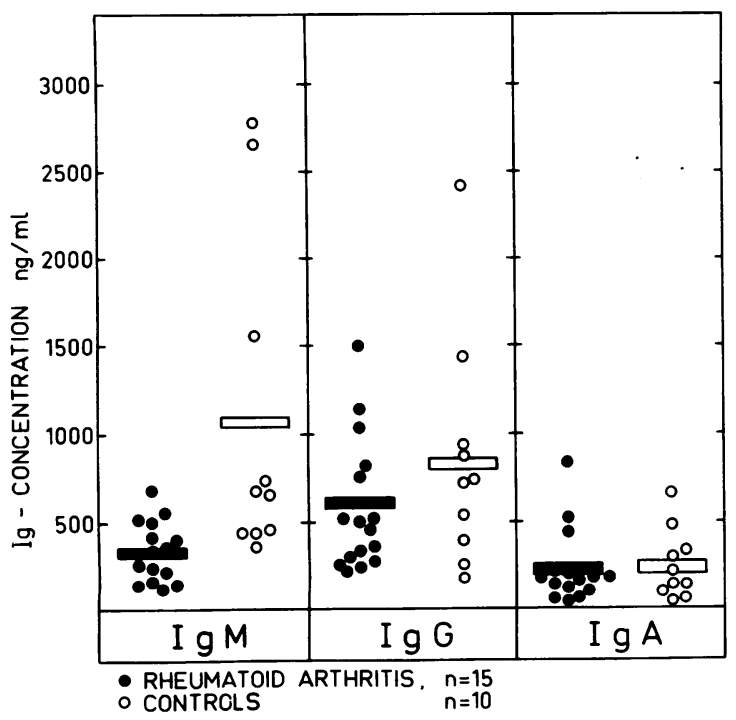

Fig. 2 Immunoglobulin concentrations in the PWM stimulated culture supernatants determined by ELISA. Bars represent arithmetic mean. The values for $R A$ patients are significantly different from healthy controls only for $\operatorname{Ig} M(p<0 \cdot 01$, Student's t test $)$. figures for IgG were $33 \%$ and $53 \%$ and those for $\operatorname{IgA}$ $61 \%$ and $72 \%$. The results cannot be explained by possible differences in cell survival, since cell viability counts after culture were similar in all groups (data not shown).

Concentration of immunoglobulins in culture supernatants. The sensitive ELISA method for detecting IgM, IgG, and IgA in the supernatants of 5-day lymphocyte cultures confirmed the above results (Fig. 2, Table 2).

Number of cells secreting IgM, IgG, or IgA spontaneously or in unstimulated cultures. Two kinds of control experiments were carried out to exclude some possible causes for the decreased synthesis of

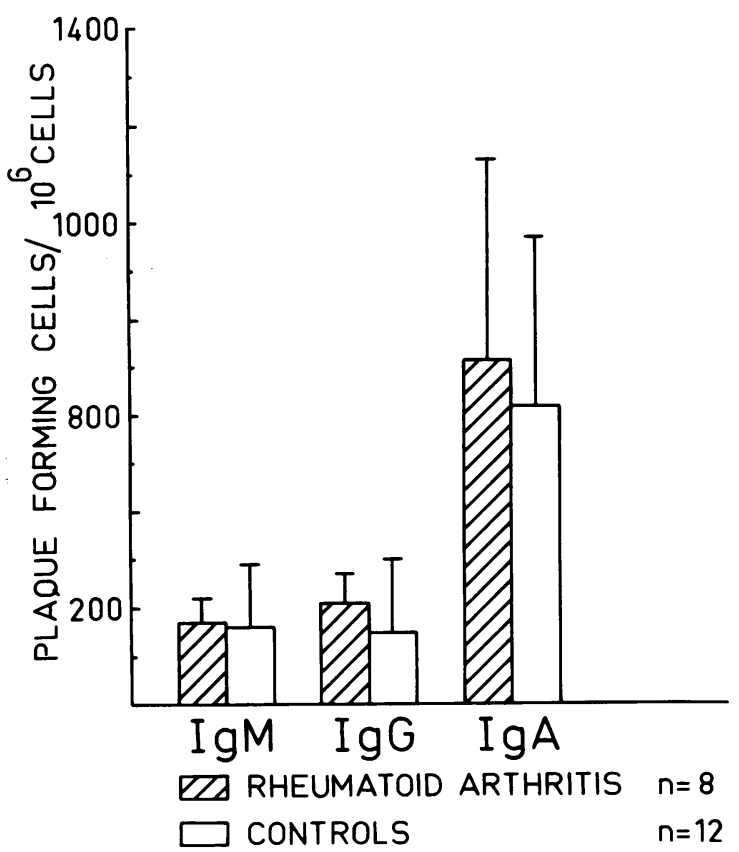

Fig. 3 Number of cells spontaneously secreting immunoglobulin in the peripheral blood of $R A$ patients and healthy controls. Results are expressed as plaque-forming cells (PFC)/10 $10^{6}$ viable cells. Bars represent standard deviation. There is no significant difference between $R A$ patients and the controls. 


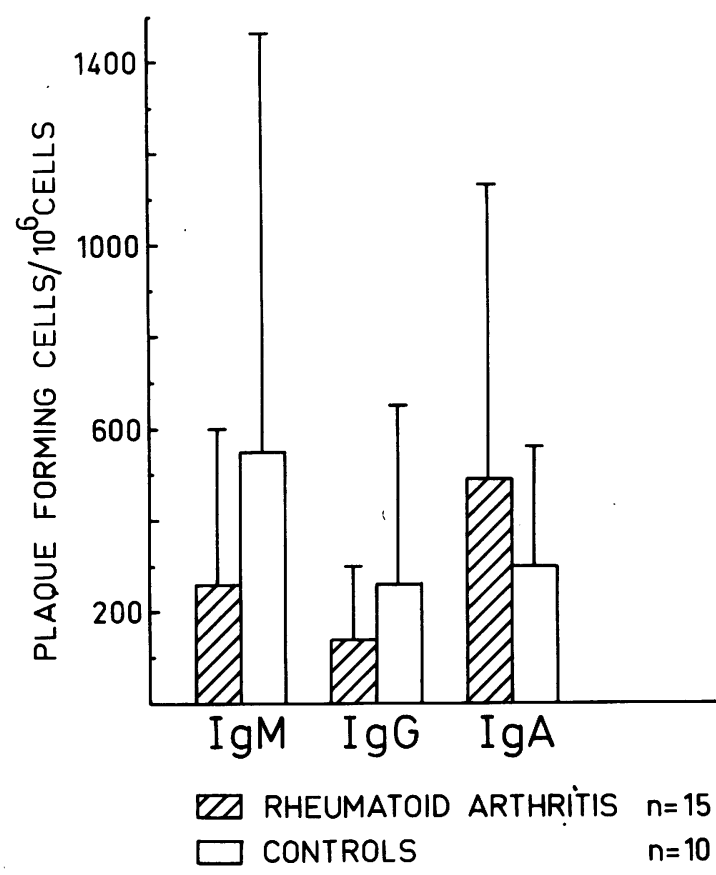

Fig. 4 Immunoglobulin-secreting cells in unstimulated lymphocyte cultures. Results are expressed as plaque-forming cells (PFC) $/ 10^{6}$ viable cells. Bars represent standard deviation. The difference between $R A$ patients and healthy controls is not significant.

immunoglobulins in RA. We reasoned that lymphocytes of RA patients might be activated in vivo, so that cells were producing antibodies from the beginning of the culture and died out before the plaque assay. This was checked by investigating the number of cells secreting immunoglobulins spontaneously, that is, by assaying the plaque-forming cells without culture. As can be seen in Fig. 3 no increase in the number of spontaneous plaques was found in RA compared to controls.

Another possible explanation was decreased sensitivity or abnormal reactivity of RA lymphocytes to the stimulant PWM. This again is unlikely, because in cultures not stimulated with PWM the same trend of decreased production of $\operatorname{IgM}$ and $\operatorname{IgG}$ was obvious (Fig. 4), though the differences were not statistically significant. If hyporesponsiveness was restricted to PWM only, one would expect equal numbers of plaques by RA and control lymphocytes in unstimulated cultures.

\section{Discussion}

This study clearly shows that the blood lymphocytes of RA patients have a decreased production of immunoglobulins, especially of IgM and IgG.
The response of RA lymphocytes to mitogens or other polyclonal stimulants has been extensively studied by lymphocyte transformation, and decreased responses have been found. Of special relevance to the present study is the work done on stimulators thought to act mainly on B lymphocytes. Thus Lloyd and Panush ${ }^{6}$ and Highton et al. ${ }^{7}$ using PWM, and Haines and Hough ${ }^{8}$ using staphylococcal protein A reported depressed response of RA cells in transformation tests. Earlier Lance and $\mathrm{Knight}^{\circ}$ found a decreased response to PWM with RA lymphocytes, but almost as low a response was obtained with cells of osteoarthritis patients. However, activation of lymphocytes into antibody production or blast transformation as well as thymidine incorporation are different phenomena, which are separable. In a recent report ${ }^{10}$ on primary antibody response to an antigen, trinitrophenyl (TNP) hapten, depressed anti-TNP IgM secretion was found.

Several explanations of depressed production of antibodies may be envisaged, including defects in B cells, monocytes, or $\mathrm{T}$ helper cells, increased activity of T suppressor cells, and the operation of humoral factors. The data of Segond et al. ${ }^{10}$ suggest normal B cell function in RA. Concanavalin-A-induced suppressor activity as well as other tests for suppressor function are also reported to be normal in RA lymphocytes. ${ }^{1011}$ Thus it remains to be discovered what mechanisms are responsible for the depressed antibody synthesis we have demonstrated.

There is an apparent contradiction between these results and the high levels of antibodies detected in rheumatoid sera. Decreased antibody production should result in low levels of immunoglobulins in serum. A similar discrepancy was reported in patients with SLE whose peripheral blood B cells showed impaired immunoglobulin synthesis after PWM stimulation. ${ }^{12}{ }^{13}$ However, it should be kept in mind that in-vitro studies are performed on blood lymphocytes. It may well be that lymphocytes actively'synthesising immunoglobulins are present in other sites such as synovial tissue. Furthermore, all the mechanisms regulating antibody response in vivo may not be present in cell cultures.

As already discussed, the explanation for the impairment of antibody synthesis in RA is not clear. We would like to think that in RA, possibly after polyclonal stimulation, ${ }^{14}$ a too vigorous antibody response takes place. The immune system thus has to use powerful mechanisms of regulation to avoid immunological exhaustion. What we see in vitro would be consistent with this state of affairs.

During this study Kari Poikonen was supported by a grant from Lääke Oy Tutkimus-ja Tiedesäätiö. We thank Mrs Pirjo Hänninen for technical assistance and Mrs Lea Holmalahti for secretarial help. 


\section{References}

1 Yu D T Y, Peter B. Cellular immunological aspects of rheumatoid arthritis. Sem Arthritis Rheum 1974; 4: 25-32.

2 Gronowicz E, Coutinho A, Melchers F. A plaque assay for all cells secreting Ig of given type or class. Eur J Immunol 1976; 6: 588-90.

3 Hammarström L, Bird A G, Britton S, Smith C I E. Pokeweed mitogen induced differentation of human $B$ cells: evaluation by a protein A haemolytic plaque assay. Immunology 1979; 38: 181-9.

4 Voller A, Bidwell D, Bartlett A. Microplate enzyme immunoassays for the immunodiagnosis of viral infections. In: Rose $\mathrm{N}$, Freedman H, eds. Manual of Clinical Immunology. Washington DC: American Society of Microbiology, 1976: 506-12.

5 Kelly B S, Levy J G, Sikora L. The use of the enzyme-linked immunosorbent assay (ELISA) for the detection and quantification of specific antibody from cell cultures. Immunology 1979; 37: 45-52.

- Lloyd T, Panush R. Cell mediated immunity in rheumatoid arthritis. J Rheumatol 1977; 4: 231-44.

${ }^{7}$ Highton J, Panayi G S, Shepherd P, Griffin J, Gibson T. Changes in immune function in patients with rheumatoid arthritis following treatment with sodium aurothiomalate. Ann Rheum Dis 1981; 40: 254-62.
${ }^{8}$ Haines R, Hough D. Lymphocyte response to mitogens in rheumatoid arthritis. Biochem Soc Trans 1978; 6: 657-9.

- Lance E M, Knight S C. Immunologic reactivity in rheumatoid arthritis. Response to mitogens. Arthritis Rheum 1974; 17: 513-20.

10 Segond P, Delfraissy J F, Galanaud P, Wallon C, Massias P, Dormont J. Depressed primary in vitro antibody response in rheumatoid arthritis. Clin Exp Immunol 1979; 37; 196-204.

11 Dobloug J H, Chattopadhyay C, Førre $\emptyset$, Høyeraal H M, Natvig J B. Con A-induced suppressor cell activity and T-lymphocyte subpopulations in peripheral blood lymphocytes of patients with rheumatoid arthritis and juvenile rheumatoid arthritis. Scand J Immunol 1981; 13: 367-73.

12 Nies K M, Stevens R H, Louie J S. Impaired immunoglobulin $\mathrm{M}$ synthesis by peripheral blood lymphocytes in systemic lupus erythematosus: a primary B-cell defect. Clin Immunol Immunopathol 1981; 19: 118-30.

13 Nushinarita S, Takizawa I, Hirai H, Morita K, Amaki I. Suppressor $\mathbf{T}$ cell dysfunction and depressed immunoglobulin production by B cells in vitro in patients with SLE. J Rheumatol 1981; 8: 19-30.

14 Möller E, Ström H, Al-Balaghi S. Role of polyclonal activation in specific immune responses (editorial). Scand J Immunol 1980; 12: 177-82. 